\title{
Diasporic Reconciliations of Politics, Love and Trauma: Susan Abulhawa's Quest for Identity in Mornings in Jenin
}

\author{
Ayman M Abu-Shomar \\ English Literature and Cultural Studies, English Department, Faculty of Languages and Translation \\ Imam Muhammad Ibn Saud Islamic University, Riyadh, 11432, P. O. box 5701, Saudi Arabia \\ E-mail: a.m.abushomar@hotmail.co.uk
}

Doi:10.7575/aiac.alls.v.6n.2p.127

URL: http://dx.doi.org/10.7575/aiac.alls.v.6n.2p. 127
Received: 08/12/2014

Accepted: 03/02/2015

\begin{abstract}
Negotiating human conditions is an emblematic critical impetus of diaspora informed by multiple cultural possibilities practiced through the creation of multiple spaces that cross the realm of the 'self' to that of the 'other'. It offers a locale to cross from the oppressed 'self' to an understanding of an oppressor 'other'. Yet, diasporic negotiation is politically involved in the most responsible manner; it engages the contextual social realities in order to enable creative possibilities for overcoming the logic of the politics altogether. It invites a kind of political involvement that assures the 'situatedness of the ethical' in a framework of moral humanistic realisations. The realisation of diasporic negotiations is dialogically engaged in manners that will give birth to new possibilities for human togetherness. In this essay, I trace the signs of diasporic negotiations of politics, love and trauma in Susan Abulhawa's Mornings in Jenin by focusing on the Diasporic identity of Amal (the central character). I consider the intersections between diaspora, dislocation of identity and the creation of negotiating spaces that qualify an 'epistemology of Diaspora' against essentialised and ethnocentric construction of realities. I argue that Abulhawa creates diasporic spaces and immense moral scenes to transcend a particular stance of politics via transcending love in opposition to suffering and tribulation. I contend that Abulhawa's conceptualisation of Diasporic negotiations enables her to depict and gauge two extreme human sentiments: love and trauma, yet, without yielding or compromising the right of just resistance and dissent.
\end{abstract}

Keywords: Diaspora, humanism, Trauma, identity, negotiating difference, and 'Otherness'

\section{Introduction}

Amy. Amal of the steadfast refugees and tragic beginnings was now Amy in the land of privilege
and plenitude. The country that flowed on the surface of life, supine beneath unwavering
skies. But no matter what facade I bought, I forever belonged to that Palestinian nation of the
banished to no place, no man, no honor. My Arabness and Palestine's primal cries were
my anchors to the world. And I found myself searching books of history for accounts that
matched the stories (p.180).

Among the rare voices of Palestinian Diaspora is Susan Abulhawa's Mornings in Jenin. Unlike the mainstream narratives addressing the Palestinian/Israeli conflict, Abulhawa, an American-Palestinian writer, construes an anomalistic compassionate voice by crafting dialogic negotiations between discrete social and political affairs of all issues she encounters in the novel. As Malouf (2011) puts it, Abulhawa manages to give such a lasting and 'terrible conflict a human face' (p. 1). Her intense sentiments of both love and trauma are coalesced into one demeanour; the human voice of being within and towards 'Love of Life', which is the love of creativity from, against, and towards difference, plurality, impasse and contradictions.

Abulhawa's novel invites a challenging reading by mixing the narratives of diverse human conditions through negotiating and transcending antagonistic predicaments informed by fragmented and dislocated memories and voices. Although, the elements of dislocated, exilic, and traumatic experiences dominate the life of the protagonist, Amal (with the long vowel; meaning the plural of 'hope', as Abulhawa insists), - her humane and motherly voice remain prevalent throughout the entire story. With this outlook, she affiliates with human "diasporic ontological existence" (Abu-Shomar, 2012), whose essence is to refuse 'counter-violence', dogma and ideology, and to disrupt essentialised constructions of realities. Mornings in Jenin is massive in terms of the myriad human conditions that the writer brings into the lives of her characters. It is an amalgam of oscillated sentiments of pain, loss, hope, dispersion, but also passionate ones; of loves friendships; personal relationships in opposition to political relations and powerful devotions to hope and understanding of otherness.

The novel explicitly reflects the indulgence of Abulhawa herself whose life is split in various cultural contexts. In one of her interviews, Abulhawa enunciates her position: "I put Amal into my life" (as cited in Snaije, 2012). In the same email interview, she remarks: 
I did not grow up around my parents very much ...In the US, I lived in the foster care system, My childhood was quite unstable and unrooted, owing mostly to family circumstances. I have mostly felt my way through life... (p. $5)$.

This explicit integration between Abulhawa and Amal has provided the author with the means to construe collective stipulations including anti-nihilism, negotiations with difference, belonging and un-belonging, and, above all, the creation of spaces that simultaneously accommodate conflicting emotions of love and trauma. For her, the interminable sense of dislocation turns out as 'productive crises' (Souza, 2007, p. 4) emanated from diasporic engagements with realities, and are empowered by epistemic contemplations or what might be referred to as an 'epistemology of diaspora' (Mishra, 1996; Tölölyan, 2012; Abu-Shomar, 2013a).

Abulhawa's diasporic identity develops as a representative of excess, rather than containment, or sense of subjectivity as split between two sites. As Deleuze and Guattari (2000) argue, "the binary logic of dichotomy has simply been replaced by biunivocal relationships, between successive circles" (p. 6). They suggest that the dialectical notion of the 'root-tree' has been supplanted, as:

the world has lost its pivot: the subject can no longer even dichotomize, but accedes to a higher unity, of ambivalence or over determination, in an always supplementary dimension to that of its object. The world has become chaos (p. 7).

Theorists insist that the symbiosis between the experience of diaspora and literature that grows in it would project a text that can be a powerful device to decode an epistemology of diaspora. Nadan perceives diaspora writings as not only a means to understand, but also a method of survival: "it has become ... not only the enigma of survival, but a way into the world, as solid mandala. Writing though fragile and vulnerable, is the only home possible" (Nadan, 2000, p. 101). Maninam (1987) argues that "fiction had been the exploration of the past, present, psychology, conflicts and ambitions" (p. 218). In the way she engages with meaning, Abulhawa's quest for identity renders visible the failure bound in binary conception, but also makes it explicit that the principles of heterogeneity and connectivity would inform a postmodern subject into a proliferation of epistemologies. Such epistemologies however bear witness an enduring value of diasporic experiences as a spring of agonised inspiration, multiple identities, new subjectivities, creative memories and fresh perspectives on language and life (Frie, 2011).

In this essay, I wish to explore Abulhawa's demeanour and dispositions of diasporic projection of identities while negotiating with extremely conflicting voices and historical realities. I discuss how Abulhawa attentively gives rise to questions of humanistic and moral sentiments in the zenith of political struggles and conflicts. Building on this, I examine how the author manages to challenge and unbind her depictions from the monolith of the 'self', and operate a human gaze for the 'Other'. I also argue that Abulhawa's delicate and exquisite voice is a product of the author's living between worlds and being 'border-crosser' between the familiar and exotic. I claim that Abulhawa imparts immense impetus to rewrite history beyond the canon of ideological representations of political conflicts, which qualifies an epistemic stance beyond the bounds of 'cultural' and 'ideological' representations of realities.

\section{Summary of the Novel}

Mornings in Jenin is Amal's narrative of her exilic and traumatic experience, yet, it is her outlook into humanism, emancipation, productive diaspora, education and hope. Marc Parent (as cited in Snaije, 2012) sees the novel as having "...everything in it. One can sense that it is a book inspired by someone's life. It's an individual story and a collective story grounded in history" (p. 3). Abulhawa construes these themes through the life experience of four generations of a Palestinian family between the years 1940 and 2002. She traces the trajectory of multiple tragedies and cataclysms of Abuilheja family who is originated in a small Palestinian village: Ein Hod. As registered in the modern history of Palestine, the year 1948 witnessed two converse affairs: the proclamation of Israel as a state for people without land, and the expulsion of the native Palestinians who are dispersed all over the globe. Like most other families, Abuilheja family was displaced into a refugee camp near Jenin in the West Bank, a place of a sort of living that witnessed their dispersion and tragic fatality. During their escape, the family lost a child Ismael who is snatched by an Israeli soldier. As a compensation for her lost hope of being a mother and the loss of her family in the Holocaust, Moshe, the Israeli soldier, gifted the child to his wife Jolanta who named him David.

Later 'David' became an Israeli soldier and is ironically made to fight his own people in wars to come. In the camp of Jenin, where Amal was born, the first three generations of Abuilheja family, (Yehya and Fatiam); (Hasan and Dalia); (Yousef and Amal) experience the indignities and suffering of the Palestinian refugees, but also friendship, memories and love. The second catastrophe of 1967 and its aftermath made it worse for the family who began to vitiate as Yehya has made his way back to Ein Hod to redeem some of his lost memories, and to read Fatiha for his wife Basima's soul, but was killed in the nostalgic journey. Amal spent most of her time with her father Hasan, who embraced her with love and care and taught her poetry. Yousef, the brother, left Jenin never to return to enlist himself in the Palestinian resistance militia. Following these tragic events, her mother lost her wits and was unable to take care of her child. Amal was sent to an orphanage in Jerusalem, where she won a scholarship to the US and remained there until she heard from her brother; the only member left of her family in Lebanon. With hope of reunion with the fragmented family and friends, she went back to Lebanon without knowing that the refugee camp of Sabra and Shatila will witness her first experience of love, but also the zenith of her tragedy through the loss of her loving husband, the only brother left and her best friend. Upon her return to the US, she gave birth to Sara whom she experienced with the inimical motherly feelings of love and pain. Unexpectedly, Amal receives a telephone call from Israel, and to her surprise, that call came 
from her lost brother Ismael or 'David'. After an awkward meeting with her Israeli brother, Amal made her last visit to Palestine in the camp of Jenin with her daughter. In 2002, Israeli troops assailed the camp of Jenin to fold the last episode of Amal's tragedy when she was killed sacrificing her daughter by taking a bullet in her back.

\section{Negotiating with difference; the quest for identity}

The quest for identity does matter for Abulhawa as it informs her narrative in several directions; it addresses the most crucial issues in constructing realities in her narrative. Abulhawa approaches the magnitude of exploring identity through a 'processional' (Sarup, 2005) resistance to the 'subversive realities' (Castells, 2004) through which she refuses consensual reception of instrumental subject-object relations as reifications of hostility and opposition encounters. Abulhawa's exilic voice, traumatic experience, proclaimed substantiations and testimonies of history - are rehearsed in "the 'inter' - the cutting edge of translation and renegotiation, the in-between space - that carries the burden of the meaning of culture" (Ashcroft, 2009, p. 14). This state of affair qualifies reference points to contemplate and mediate in the zones of conflict and suffering as well as those of the self and 'Other'. Abulhawa emanates her themes as a spring of her own agonised inspiration, multiple identities, new subjectivities, creative memories and fresh perspectives on language and life. As Snaije (2012) describes:

this rootlessness comes across in Amal, the main character in Mornings in Jenin, who is a gifted student and earns a scholarship to study in the US. Her raw loneliness and seeming aloofness, a result of the emotional trauma she has been through, is described in such intensity that it seems impossible that Amal is not Susan Abulhawa (p. 7).

Throughout her narrative, Abulhawa's experience of diaspora, with its connection to forming her identity, grows up as a 'survival strategy' to contest with binary oppositions while representing the 'Other'. Her multiple voices and perspectives mount up into making the central character ( $\mathrm{Amal}$; the visible narrator) an icon who escorts thriving negotiations with difference in the zenith of human struggle. She enunciates and maintains a nonpartisan humanistic voice when articulating her inner dialogue with agitation and rupture. The novel opens and closes with Amal staring down at the barrel of a young Israeli soldier's gun who is about to shoot her in the camp of Jenin.

AMAL WANTED A CLOSER look into the soldier's eyes, but the muzzle of his automatic rifle, pressed against her forehead, would not allow it. Still, she was close enough to see that he wore contacts. She imagined the soldier leaning into a mirror to insert the lenses in his eyes before getting dressed to kill. Strange, she thought, the things you think about in the district between life and death (p, III).

In this opening scene, Abulhawa introduces Amal's inner dialogic contact with a forbearing benevolence beyond the hostility of war. She uses this mood of engagements with realities to established her humane stance towards what is 'beyond the immediate' into a benignancy of the orgiginary of the potentials of a human being. Amal's concerns are more to understand what it could mean for a human fellow to waste another's life than those agonies informed by the vices and hostilities of war. She towers up the normal feelings of someone about to face death and steps into mediating sympathetic accounts for the Israeli young soldier, and envisions the soldier as a person of fortunate future with more auspicious potentials than just turning into a killer. Although Abulhawa evokes a sense of meditations on the whole idea of death and the moments that precede it, she troubles this narrative by recalling a 'diasporic vision of reality' (AbuShomar, 2013b), and perceives life as a form of art, and by making possible much more than normal feelings of violence in the hope of love and creativity. Such a locus of enunciation offers her empowering tools for deciphering the critical ethics of the moment by improvising and negotiating with enmity beyond mere political encounter between individuals.

Throughout the novel, this liminal state is consummating for Amal as it generates a critical space in which she becomes towards the 'Other' in a mounting loving passion than anything else. As Amal is stepping into the realm of that 'Other', she becomes closer enough to read the Israeli young soldier's inner worthy and latent human virtues to overcome the reification of politics in the face of humanism. Toward the end of the tale, Amal remarks

He blinks hard. And a solitary drop of sweat travels from his brow. Down the side of his face. I watch it fall and note his smooth skin, still too young to need a regular shave. The power he holds over life is a staggering burden for so young a man.

He knows it and wants it lifted. He is too handsome not to have a girlfriend nervously waiting for his return. He would rather be with her than with his conscience. With his burden or with me.

I know he has killed before. He knows I know. But he has never seen his victim's face. My eyes, soft with a mother's love and a dead woman's calm, weigh him down with his own power and I think he will cry. Not now. Later. When he is face-to-face with his dreams and his future.

I feel sad for him. Sad for the boy bound to the killer. I am sad for the youth betrayed by their leaders for symbols and flags and war and power. For an instant, I think he could be my nephew. But no. Uri has no doubts of his duty to kill for Israel. This soldier is not my nephew.

Strange, strange, he is handsome and I, loving (p. 305-6).

Upon her return from the US and before this encounter scene, Amal makes a visit to the occupied territories (known as 1948 territories) to meet her father's (Hasan) best childhood friend Ari Perlstein, the son of a Jewish German professor, who is now an old bachelor professor. The childhood friendship that preceded the outbreak of wars and political conflict is informative to Amal's understanding and outlook of the young soldier's case who, as she perceives, is betrayed by his 
"leaders", “symbols”, “flags”, “war' and "power”. Her sympathetic remarks towards the young soldier, in particular, relates to a negotiating monologue between the memories of pre-war friendships, diaspora, motherhood, and grief of a lost brother. Her negotiations with these contesting ideas destabilise polarised depictions into a meaningful wholeness that suggests splits and fragmentations informed by multiple outlooks into realities (Fernandez, 2009).

Through an act of abstraction, or dissociating these contestable ideas from their historical context, she moves beyond dialectic binaries into a dialogic act of understanding otherness. Abulhawa's involvement of a dialogic act between herself and the soldier enables her to articulate the meanings of the soldier's ideas, and then, "at least two voices are heard simultaneously" (Bakhtin, 1986). Her search of such a dialogic act would enable a position of what I call 'critical consciousness', which potentially reflects 'third space positioning' (Abu-Shomar, 2012) where identities are always in flux, split between two or more worlds, cultures, and languages. In the encounter scene with the soldier, she becomes worried about the soldier's girlfriend as much as she is worried about her own daughter who is also within the reach of the soldier's gunfire. Her critical consciousness enables a humane voice that eludes the fact that the soldier "has killed before", and of being responsible for her ultimate tragedy of losses and pain. Her remark: "My eyes, soft with a mother's love and a dead woman's calm, weigh him down with his own power and I think he will cry" (p. 305), in particular is a significant indication of a deep inner critical consciousness her.

The triangulation of friendships, diaspora and motherhood of Amal has furthermore projected a rather unusual means of perceiving meanings; her boundedness to surrounding realities is consistently troubled through the intervention of her liminal state of diaspora, a sort of being whose essence is a refusal of 'counter-violence'. In her moments of differentiation and negotiation, Amal enunciates this moment while contemplating with the young soldier: "I feel sad for him. Sad for the boy bound to the killer. I am sad for the youth betrayed by their leaders for symbols and flags and war and power" (p. 306). Amal's creation of these spaces enunciates an ultimate denouncement of politics where "flags" and nationalism become threat to humanistic understanding of otherness. While searching for shared elements of human intimacy, he consummates a courageous locale where she places an upper hand on the politics altogether. For her, "dreams" and "future" become conceptual icons in the face of the "betrayal" of politics and "leaders". Amal's sense of this liminal state mounts up as a 'productive crisis' through which her encounter of discrete sentiments and conditions becomes a moment of ethical differentiation and negotiation. For her, the crisis evolves as abstracted critical spaces rather than concrete sites, and, then, identity can be made and re-made in the movement from one self to another. Consequently, the creation of the new selfhood in such spaces enables further ontological subject positions that acknowledge the difference and hybridisation as imputes for enunciating humanistic conceptualisations.

Between these two encounter scenes (at the beginning and end of the novel), Abulhawa waves multi-trajectory narratives of people whose lives are subject to relational exchange of intertwined and complicated history and political struggle. In the early times and before the breaking off the political conflict in Palestine, Abulhawa insists to present the human side of all her characters. She commenced the tale with accentuating the intemperate friendship between two Palestinian (Abulheja) and Jewish (Perlstein) families in the village of Ein Hod. For Abulhawa, this early foundation of equitable sentiments is significant in building human relationships between people of different cultures and religions erstwhile to the corruption of political interference. This sense of platonic personal and humanistic friendship is consolidated by the intimate relations between the children of the two families Ari and Hasan, and their mothers Basima and Mrs. Perlstein who backed up the friendship of their children by exchanging food and taking care of them while they are visiting each other's homes.

Not until these relations had been disrupted by the militarised Zionist terrorist gangs' attacks, and the wars to follow, Abulhawa provides otherworldly scenes of the coexistence of different people in their endemic ways in Ein Hod. The little and humble matters and stories of the two families are such examples of the unblemished intercultural relations that remain pure and not distorted by the "filthy politics and injustice" (p. 208). For Abulhawa, these early years comprise platonic times that will never be repeated in what yet to come; Yehya would touch his olive trees to "resurrect simplicity and peace" (p. 25). Those early years represent the revelation of human response ability in its endless creative possibilities beyond cultural divide, political interests, racial and national differences. All throughout the novel, Abulhawa insists on referring to those times as the most intimate manifestations of becoming-towards-the-world of shared responsibility, love creation and happiness. For her, the village of Ein Hod is the utopian place that is rooted in history, but also a signification of an abstracted idea of unyielding place to politics: they [villagers of Ein Hod ...] want only to live on their land as they always had. For they had endured many masters - Romans, Byzantines, Crusaders, Ottomans, British — and nationalism was inconsequential (p. 32).

Nonetheless, the agony of 'dislocation and disposition' (Hunt, 2010) remains an active demeanour for Abulhawa in her depiction of the old village of Ein Hod. The song of love however remains the backdrop that informs the way she construes narrative. The tragic dislocation of the Palestinians in 1948 invites traumatic shade of the originality of love that keeps haunting around the ways these villagers could comprehend what happened to them:

In the sorrow of a history buried alive, the year 1948 in Palestine fell from the calendar into exile, ceasing to reckon the marching count of days, months, and years, instead becoming an infinite mist of one moment in history (p. 42).

These feelings are however coloured with contentment: while Yehya narrates his experience upon his last visit to Ein Hod after the occupation: "the villagers ate, laughed, wept, danced, and sang the sad and happy ballads of old, comparing their memories to Yehya's description of the new state of affairs" (p. 52). As Bhabha (1994) reminds us, the 'psychic process of identification' becomes an interpretive mode to deal with the juxtapositions of memories. For those 
villagers, the act of comparing is constructed as a sense of being that constantly oscillates between the axioms of acceptance and repulsion. The villagers' current conditions of exile are merged in the jubilant memories of the past to create a combination of 'time lag' and constant formation of their identities. Their subject-positions or mixed feelings are formed via excess the sum of the 'parts' of their fragmented memories, and "The air filled with carousing sounds and people were drunk on the fruits of trees that had continued in time and penetrated the cloud of exile" (p. 54).

Like the village of Ein Hod, the Old Lady, an old olive tree, has become an emblem of 'psychic process of identification': "Baba once told me that no one owned Old Lady. This old girl was here long before any of us, and she'll be here long after we're gone"” (p. 69). Hajj Salem, out of his wisdom, also keeps calling the Old Lady an "old staff". Yehya and Hajj Salem rejoice Old Lady as a symbol of untouched purity that refuses ownership, and a dazzling example of rootedness and belonging. For Amal, her father's words encompass an idol image and old wisdom onto how she later comes to perceive meanings around her. For example, when she excels on the meaning of ownership, she would recall her father's words, "No one can own a tree ... It can belong to you, as you can belong to it. We come from the land, give our love and labour to her, and she nurtures us in return. When we die, we return to the land" (p.72). Yet, Old Lady is troubling to Amal's search for resolution of her identity since Old Lady is charged with the idea of rootedness and belonging. Old Lady brings about an ambivalent and undecided identity, or unconscious connection between Amal's diasporic mind and her Palestinian identity. The defiance between Amal's fragmented identity and the stability of the Old Lady calls her to a process of negotiation, identification or re-identification of old concepts. For her, the answers of troubling questions, "can be found in the sky if you looks enough and hard enough, [and] the arrangement of stars were divine hieroglyphics that could be deciphered by faithful hearts" (p. 162). While earthy answers are contaminated by political ideological accounts, the "tapestry of the stars" (the state-of-the-art source of meanings) provides Amal with appealing answers to her dilemma. Amal reasons:

To that tapestry of stars, I offered up my greatest wound. There was nothing left for me in Jenin but scraps of my childhood and the debris of the family lost forever ... If I returned, unavoidable marriage awaited me in the traditional culture of Jenin's refugee camp. My awful scar, my disfigured body, made me dread marriage, which would surely bring a new flavour of rejection and abandonment (p. 162).

In the zenith of the predicaments between her Western feminist voice and the demands of being an overprotected girl as informed by her oriental background, Amal seeks rectification by fusing a process of 'nexus of exchange' (Moor, 1994). For her, the nexus of exchange becomes a process for dialogic cultural negotiations beyond 'polarisation' where she invites a non-oppositional 'pragmatics' of choices of losing, yet surviving struggles. For example, while she negotiates her sexuality in terms of the Arab culture, which requires that a "female needs for a caring man", she places her faith, hence, decision on her late father's wisdom who perceives education as the core of emancipation, security and selfreliance. Within this dialogic exchange, Amal trades off manhood protection with that of education and makes the decision to proceed in her plans toward her academic future in the US. Rather than adopting a utilitarian position, I realise this decision of Amal as a dialogic exchange of the dynamics of culture. For her, the dialogue between a woman's body and the body of knowledge signifies discourse of power for the colonised subject. Amal's reflective manner, however, seems to resolve the tension generated by these two contestable obligations. For her, dialogical cultural exchange survives both ends; her culture obligations and pursue of education. As dialogics survival maintains difference within the dynamics of opposition, culture operates outside the terms of the struggle because. Amal's resistance, thus, becomes, heteroglossic since exchange allows "multiple voices in collaboration, not in a utopian sense but in the sense of mutual cultural dynamics rather than hegemonic cultural domination or inertia" (Moore, 1994, p. 18).

\section{Trajectory of Diaspora: Amal between Worlds}

As she grows up, the trajectory of Amal's condition of diaspora develops into a lasting labyrinthine between displacement, victimisation, alienation, geographic dislocation and a crossing-of-borders. Amal's journey to the US, Lebanon, US again, and finally Palestine (Jenin) construes a physical and psychological trajectory of enigmatic exilic survival created by multitude of influential events in her life. Her first visit to the US was after winning a scholarship, which counts for a sign of 'emancipation' acquired through education and knowledge, but also of conflict between a trouble-free and plain girl into the 'liberal' of Westernised education. After the news from her brother Yousef, Amal travels to Lebanon to reunite with her family and her close friend Fatima. In the exilic camp of Sabra and Shatila the 'family' recalled and celebrated the memories of childhood. More to her in the camp, she experienced the romance and passion of the oriental Arab love, and that when she met Majid, an educated doctor. After a short mirage, the war broke off, and Amal had to leave again to the US carrying the "fruit" of that marriage in her womb. In the US when she heard the news of her tragic loss of her husband, and her best friend, Amal led a "besieged" life of the "unbearable sorrow of extinguished love" (p. 228). When the "trickery of destiny" brought her the news of her lost brother (Ismael, David), she returned to Palestine with her 16-year-old child, Sara. In this final journey, she closed the last chapter of her life trying to defend her child from the gunshot of an Israeli soldier. These experiences create conflictual and competing feelings of joy and sorrow, which produce a fragmented sense of the self for Amal. In this section I discuss Amal's trajectory of this experience, and how she responds to the complications of her hyphenated identity that informs a dualistic, reversal and convergence of consciousness, or otherwise.

In the US for the first time, Amal begins to develop feelings of inadequacy as she flounders in the enticing world of unfettered individualism. Although such psychological and geographical dislocation is not unusual for someone like her who has left behind a place of military violence and entered the relative safety of North America, Amal finds a place of escape in the illusion of a historicity in US mainstream culture. She then consciously begins to participate in the illusion 
offered by the host culture. She is now divided between the emancipated life of the Western education with the risks it may bring, and being at 'home' satisfied with a predictable, easy and secure life. In other words, Amal becomes caught between two diverging roads of liberal Western culture and education and the conservative oriental Arab life style. Her Western liberal education becomes heavily marked and inhabited with boundless and limitless feminism that allowed her to have a sexual relationship outside the bondage of marriage.

Like other Palestinians who escape the violence of war and occupation, Amal finds a tentative safe, undisturbed or peaceful refuge and peace. In Amal's case she becomes involved and engaged with promises of a new life in the New World - she begins by renaming herself. She Anglocizes her name and becomes Amy: Amal of the steadfast refugees and tragic beginnings is now Amy in the land of privilege and plenitude, "the country that flowed on the surface of life, supine beneath unwavering skies" (p. 80). Symbolically, Amal's mind suppresses her complicated Palestinian identity and seeks refuge in a simplified American being with the name Amy. This further entails burying or veiling what has become discourses of violence and terrorism (from an American point of view) instead of discourses of resistance and opposition. Amal abandons the Palestinian history of resistance to Israeli annihilation encoded in her very name by becoming the clipped 'Amy'. As Amy, Amal searches for psychological self-centred wholeness more than refuge; she hopes to leave behind the miseries that are associated with her homeland. In striving to become an 'unhypenated' American, Amal learns to tamp down the memories of her Palestinian girl-self so that she can live an illusion of not having a sedimented difficult violent history; by becoming the American Amy, she hopes to leave behind the messiness of her Palestinian heritage:

but the Palestinian girl of pitiable beginnings was trampled in my rush to belong and find relevance in the West. I dampened my senses to the world, tucking myself into an American niche with no past. For the first time I lived without threats and the sediments of war. I lived free of soldiers, free of inherited dreams and martyrs tugging at my hands (p. 174).

Nonetheless, Amal cannot leave behind the ghost of history; as she quickly intuits, "every house has its demons" (p. 174). In the US, and for the rest of her narrative, Amal develops a sense of "uncanny" (Bahbah, 1994) or how the past haunts the present where ghosts are rising up to challenge her in adopting the illusion of American self-contained uninvolvement identity. Amal's, exploration of the meaning of the hyphen in her identity develops into a divide and a torture; she is not able to "press the hyphen too far for the fear that this would lead to massive communal schizophrenia" (Vijay Mishra, 2005, p. 134). Eventually, Amal resists her feeling in nostalgia or what might be called 'negative utopia'; during this phase of her life, she keeps on referring to her yearnings as "sweet nostalgia"; in other words, she desires to be "milted" in her new life, replacing Amal with Amy: "No soldiers here. No barbed wire or zones off-limits to Palestinians. No one to judge me. No resistance or cries or chants" (p. 179).

In the entanglement and mystification of her emergent realities and conflicts, Amal develops feelings of 'uncanniness' (Bhabha, 1994). Bhabha uses 'the uncanny' or 'uncanniness' to characterise the psychological experience and conditions of complicity and resistance on the part of colonised subjects. He claims that colonial psychic economy of monstrous doubling with his uncanny to explain the feelings we get when experiences of childhood that have repressed return to disrupt our everyday existence. The idea of Bhabha's uncanny helps reading Amal's stance of struggles over her dual identity and consciousness, and to think about "the possibility that the last sector of humanity, forced into remaining static, has a relationship to home which is actually similar to the migrant's" (ibid, p. 196). Amal's uncanniness intensifies when the question of her struggle over wholeness is involved. Throughout her narrative, she flounders over myriad incompatible conditions including issues of belonging and unbelonging, sexuality, emancipation, nationhood, familial and social ties and commitments, among several others.

In the US, Amal explores the triangulated relationship between the self, time and place as sufficient sources for meanings. In her search to coincide with the fragmented self, she launches into a mutable monologue of memories of 'home', whatsoever home is. For her, these memories "would become the chronicles of times", and in the "years of nostalgia"; they "had much of the staff to warm the soul" (p. 182). Yet, as Bhabha argues, uncanniness is not only a question of place, but also of time: because our sense of national identity is both static and open. We do not own our nation, as it is something that is simultaneously our own and not our own, because its identity is always coming from the future, or, in short, changing. The intensification and magnitude of Amal's uncanniness is augmented when her reversal consciousness informed by her implanted memories troubles her search for wholeness and stability. She recons:

The divide could not have been greater, nor could it be bridged.That's how it was. Palestine would just rise up from my bones into the center of my new life, unannounced. In class, at a bar, strolling through the city. Without warning, the weeping willows of Rittenhouse Square would turn into Jenin's fig trees reaching down to offer me the fruit. It was a persistent pull, living in the cells of my body, calling me to myself. Then it would slouch back into latency (p. 175).

The time lag of Amal's memories would become unhomely as it evokes the uncanniness of her experience of diaspora through a series of familiar ideas like-half-life, (like the partial presence of colonial identity), repeats the life lived in the country of origin, but this repetition is not identical, introducing difference and transformation (Bhabha, 1994). This difference in repetition, as Bhabha argues, is a way of reviving that past life, of keeping it alive in the present. Bhabha also claims that the idea of the uncanny is itself ambivalent; all the hesitations, uncertainties and ambivalences with which the split in the political subject, and the way new contexts change the meaning of a statement. The resurgence of Palestine from Amal's "bones" into the "centre" of her "new life" is now domineering, yet, "unannounced". It evokes involuntary recurrence of her political 'self' through the old and familiar; between the 
haunting memories of her childhood in Jenin with all its political bearings and her new seemingly stable life in the US. Bhabha insists that uncanny is similar to Freud's 'repetition compulsion', where uncanny opens a space for us to reconsider how we have come to be who we are. "In class", "at the bar", "strolling through the city" and "the weeping willows of Rittenhouse Square", — and all other stipulations of her new life would be repeated in her mind, but swayed and forged by the past memories of "Jenin's fig trees". Through self-observation and self-objectification, Amal is caught in ambivalent state between reconciliation and dismantle; between the homely self-asserting its coherence and stability (as it is made meaningful by those to whom it belongs), and the unhomely self as it is always changing, and is always being made meaningful by others. Bhabha contends that

culture has dual identity, as it is never quite coherent and self-sufficient. Its narratives seem stable and confident, but they always get drawn into strange displaced relationships- with other cultures, or texts, or disciplines. So he states ahead that the migrants can exemplify the dual nature of culture, always situated in relation to both an original culture and a new location (1994, p. 194).

In the US, Amal's condition of "wandering in and out" the American culture or what she calls "cultural vicissitude" speaks a lot of her uncanniness and ambivalent experience. Amal's strivings to unhapyhnated and stable identity through identifying with the American ethos are interrupted by a repetitive compulsion informed by tedious and rhythmic feelings of guilt informed by her past:

I spun in cultural vicissitude, wandering in and out of the American ethos until I lost my way. I fell in love with Americans and even felt that love reciprocated. I lived in the present, keeping the past hidden away... But sometimes the blink of my eye was a twitch of contrition that brought me face-to-face with the past ( $p$. 174).

Thus, in her search to reconcile with fragmentations and inconsistencies, Amal's wanders between the elements of history in a lasting movement between the ethos of diverse cultures. When she rips from her own past memories and places them into her new life that is rolling over her, Amal would put two consciousnesses of two clashing souls in her oriental self. To borrow Du Bois's (1994) words, Amal cleaves to two 'peculiar sensations', of double consciousness, where her 'two-ness' (as an American and an Arab); her 'two unreconciled strivings'; 'two warring ideals' are forced into a desired whole or one-ness. Amal's resistance and reconciliation, thus, give expression to an imaginary identity of 'double bind', 'split perception' or 'double vision'. She seeks resistance by making compromises in a double process of cleaving from and to her host culture: cleaving from, moving away from Western ethos and transgressing its boundaries; and to do this, cleaving to: appropriating the past ethos of her as an Arab. Amal reasons "the undercurrent of my life in America was a sense of shame that I had betrayed my family — or worse, myself. But I consigned myself to American mores and subscribed to their liberties" (p. 174).

\section{The otherness of the 'Other'; the quest for moral humanism}

In the last part of the study, I explore the possible links between Abulhawa's engagements with the notions of otherness and the 'Other' from a diasporic position as locus of epistemic enunciation and the humanistic outlook towards the 'Other'. Notwithstanding her double vision of realities informed by her hyphenated identity, Abulhawa maintains a sense of ethical humanism and moral dicta while speaking and voicing the Israeli characters. As Khan (2010) comments, "what strikes readers most is the honesty of the author's voice" (p. 2). Despite the fact that Abulhawa herself has experienced the tragedy of dislocation and exile, she does not allow her personal feelings fill the text. She portrays all individual Jewish characters in sympathetic light with deep humane understandings. Khan contends: "Nowhere in the story has she lost the touch of humanity" (p. 1). I claim that Abulhawa's depictions of the 'Other' are informed by her human ontological being mounting as a diasporic eternal-improviser that is never controlled or swallowed by political or ideological systems. By reconfiguring the selfhood and the 'Other', Abulhawa could reconstruct or reconfigure both intimacy and resistance, and, then, becomes intimate with the humanity and Love, on the one end, and resistance to oppression and injustice, on the other.

Among the iterated locations where Abulhawa engages with a humanistic outlook towards the 'Other', I highlight those related to the Israeli family who kidnapped and raised her brother Ismael. Although, Amal's narrative of the Israeli family echoes the consciousness of a high sense of guilt on the side of the Jewish family, her representations do not go far from a reversal consciousness that unbinds her vision of reality from the conduct of political struggle. When humanism encounters the politics of representation, Amal needs myriad approving sentiments to surpass her own 'insidious trauma' that oblige her to reconstruct her perceptions of the world around her beyond the incorporation of her traumatic experience (Assif, 2014). In her representation of Jolanta the 'mother' of Ismael (David), Amal reasons:

Jolanta gave her blessing for David to do whatever his heart commanded. Be he Jew or Gentile, Jolanta loved that boy. God only knows how much. That love had saved her once upon a time. Jolanta had done what neither Dalia nor Amal could do: she had transformed the energy of her pain into expressions of love, and David was the sole beneficiary (p. 257).

The question of how to articulate a logic of the human - and, hence, a form of humanism - that calls us to be true to ourselves in the first place - is ultimately Amal's condition of "wandering in and out", or what she calls "cultural vicissitude". Amal expresses an intense rational moment of muddled sentiments towards Jolanta, which marks a salient move towards resisting ideological representations, whether those of Jolanta, Moshe, Ari or the young soldier who shot and killed her. Through acknowledging Jolanta's pain of losing her family and her inability to have children of her own, Amal maximises her motherly selfhood with that of Jolanta's; the self that speaks of Jolanta is that of a double- 
voice enunciating her depictions in a new language in which meanings become 'multi-accentual'. Through her dispersed voice and immediate sense of humanism, she realises how much love could Jolanta offer to her child, the Arab, and in placing her 'self', in appraisal, Amal makes Jolanta win over her as if the pain of Jolanta, not only akin to hers, but supersedes that of her and that of Dalia, her mother. As such, pain, love, the self and otherness are all articulated through undecided, intricate and multifarious process. Amal's pain transcends to an open-ended space for all who suffer regardless of which side of the struggles they are located. For Amal, the pains of the two mothers (Dalia and Jolanta) outdo other national or political differences: Dalia's pain (her loss of the whole family, and, on the top of that, her loss of a child who is snatched from her arms upon her refuge escape), and Jolanta's loss of her entire family in the holocaust and of being sterile. As complex as these bearings of Amal are, they divulge her disheartening experiences and the sense of alienation in diaspora, which have enabled her to destroy that ancient wall of otherness. However, the sense of remoteness, seclusion and solitude that she could not overcome in her American life reflects a deeper level of conflict where she embraces the 'Other', but cannot be one with it. As Kristeva (1991) puts it,

making ourselves alien to ourselves is a necessary position from which to support non-hierarchical relations to difference. It is not simply - humanistically - a matter of our being able to accept the other, but of being in his [/her] place, and this means to imagine and make oneself other for oneself (p. 64).

Nonetheless, Abulhawa insists that to be true to oneself is a contingency for the ethical infinity of the moment that requires truthfulness and right doings; Jolanta needs such a humanistic moment that demands acknowledgment of David's real identity. Through the eyes of Amal, Abulhawa reasons:

For if life had taught her anything, it was that healing and peace can begin only with acknowledgment of wrongs committed. And only then was Jolanta truly sure that David was, indeed, her son. The truth set her free and she found the urgent path of peace, where religion and history bowed before the sympathies of two mothers forever joined by their love for one boy (p. 257).

Said (2004) argues that the counter-logic of humanism is never simply an exercise in idealist thought; rather, it is something that actually lives and calls for equitable and shared future, and hence of building on an understanding of what it means to develop a human community with rather than against other human beings. The idea of humanism of liberation is affirmative and productive; creative of new relationships, but not an idealised abstraction to which reality should have to adjust itself. Therefore, Jolanta's acknowledgement of "her wrong deeds" would elevate her to higher and infinite capacity of motherhood. Only, then, Jolanta's true love would approve and transcendent its humanistic worth, and when reality is no longer subject to adjustment and compromise.

Amal ratifies that Jolanta's confession of truth will set her free so that she can find her path to peace, and to the untroubled motherly love. Amal perceives the doctrines of nationalism and politics as impediments to moral humanism; the chronic of such orthodox doctrines "bows" or yields in favour of the power of motherly love. Yet, for this love to yield, she avows the pronouncement of reality without adjustments so that the oppressed can coincide with the complications of such a stance of moral humanism (see below).

Not only Abulhawa's humanistic depiction of the 'other' is revealed through her understanding of Jolanta's motherly case, but also that of Moshe with all his wrong deeds especially kidnapping an infant from the hands of his refugee mother. While Abulhawa rejects the manipulative role of history and memories for Jolanta as one belonging to the hostile 'Other', she acknowledges their positive utility in the case of Moshe who recalls the tragic history of the Jews that makes him understand Jolanta's sufferings as a broken and fragile woman seeking refuge like thousands of other Jews' suffering denial and dislocations. Yet, more to Abulhawa's stance of moral humanism is the particular attention she pays to dialoguing with Moshe's endeavours around the action of kidnapping Ismael and its catastrophic aftermath on Abulhaija family. In the moments of differentiating the ethics of the unadjusted truth, Amal speaks the mind of Moshe:

Moshe had wanted David to know what had happened all those years ago. His gift to Jolanta in 1948 had grown into a secret too heavy to carry. That truth was not a butterfly but a demon - a demon with the beautiful face of an Arab woman who had served him lamb.

Whose sons, one at her chest and the other at her legs, had moved with her, and who still cried, "Ibni, ibni!" inside Moshe's head.

He had not wanted all this. He had wanted wholeness: a homeland, a wife, a family. He had fought to save the Jewish people. But at his heels now were the awful evictions, the killings, the rapes. Moshe could not face all those faces, their voices. He found so little rest in his life (P. 102).

Abulhawa speaks of a language with rather than for that 'Other', where the notion of 'subject-in-process' emphasises being vigilant recuperation of the stranger within. For her, Moshe's endeavours of kidnapping of Ismael linger around moral and malicious intentions. While it could be easily taken up for the latter, Abulhawa contemplates sharing Moshe's outlook of someone who dreams of the wholeness of homeland, wife and family; a 'victim' of 'selfhood' who is not yet stripped from his humane ideals as he seeks the moment of confession to unburden his heart from his wrong deeds. Abulhawa reaches beyond her own individuality by extending the boundaries of the private realm into that particular 'Other'; a specific 'Other' (e.g. Moshe), and through this 'Other', she steps into the generalised 'Other'. In her search for a humanistic outlook for this hostile 'Other', Abulhawa, embraces the idea of 'otherness' to be open to reconciliation between the whole and difference. Yet, wholeness requires stable identity, which ultimately summons into it as a way to move the necessary circle back to the self. In consequence of her struggle over her own wholeness, 
Abulhawa's stance of humanism incorporates to her 'diasporic reconciliations' informed by her Westernized or Americanized thought and theories segregated from their cultural backgrounds. To my understanding, Abulhawa's outlook of humanism is an attempt from a diasporic 'Other' to embrace its 'one' other by seeking synchronisation, agreement, and approval from within her disturbed worlds and diasporic identities or both. In Abulhawa's words, her characters "wanted wholeness" in a dispersed and scattered world which had denied them alterity and distinctiveness. Her own case of alienation and estrangement brings about an inner struggle to coincide with humanism, or as Said (2004) contends: humanism is a struggle “to dissolve Blake's 'mind-frog'd manacles' so as to be able to use one's mind historically and rationally for the purpose of reflective understanding” (p. 142).

\section{Conclusion}

The tale Mornings in Jenin of Abulhawa is massive in terms of its engagement with meaning from a diasporic standpoint or position. Through creating diasporic spaces of negotiation and reconciliation, Abulhawa deconstructs the frozen, boundaries of temporality and politics, and realises the moral "responsibility to trace the other in self [and to seek living] fearlessly with and within difference" (Dunlop, 1999, p. 68). Nonetheless, Abulhawa's strivings for reconciliations are contingent upon her divide and diasporic identity, and the connections between 'roots' and 'routes' (Clifford, 1997) has never been an easy task for her. Withholding the impasse of her 'historical rift between locations', she manages to redeem the fragments of the self from its own thingness, and recognises that morality necessitates an understanding of the 'Other' to be altogether outside the realm and boundaries of the self. As I have attempted to argue, Abulhawa's diasporic engagement with the difference, and 'otherness' (and in her case, a hostile 'Other'), obligates her to resist associations that obscures and covers up the presence of the 'Other'.

The task of reading Mornings in Jenin is challenging as it relates to the exilic voice that diffuses dramatic triangulation of love and trauma in the times of war and political conflict with its loops in time, history and memory. The associations of diasporic identity with the Israeli occupation of Palestine and its aftermath have become central themes in the novel. For Abulhawa, diaspora brings about profound adaptations in the epistemologies while reading the politics of the Palestinian Israeli conflict. Her experience of exile and displacement or "the politics of dispossession", as Said (1994) puts it, - have informed a multitude of interspersed themes in her narratives. The diasporic psychological experience of Amal, has informed a narrative of creative improvisations and negotiations with contestable ideas. Thus, the act of negotiation, where identity is involved, is no longer between two discrete positions or vistas, it is rather an inner dialogue informed by dislocated, nonpartisan middle-of-road and clinical locales.

Abulhawa's novels is indeed 'too thick', not only in depicting the loving tragedy, as Yassin-Kassab (2010) suggests, but also through the creation of human tapestries of all threads and colours weaved to draw a humanistic visions at the times of wars. The challenging task of reading the novel, thus, involves myriad human conditions: her passionate reflections on love, beauty, motherly voice; the unprejudiced and humane understanding of the 'Other'; exilic placement and displacement; politics and struggle; inner conflicts of dispossessions; and, most importantly, the humane voice through which she construes all of these themes. All of these themes have become merged in the diasporic mind of Abulhawa, and this combination has rendered her novel a inimitable and rare voice at times where ideologically informed representation seem to prevail most of the writings around the Palestinian Israeli conflict.

\section{References}

Abulhawa, S. (2010). Mornings in Jenin. New York: Bloomsbury.

Abu-Shomar, A. (2012). Dialogic Spaces: The Potential for Interrogating the Cultural constructs of the English Literary Canon in Postcolonial contexts, Lexington Books, KY, USA.

Abu-Shomar, A. (2013a). Critical Spaces of Diaspora for liquid post-modernity, Journal of Postcolonial Cultures and Societies, 4 (3), pp. 1-14.

Abu-Shomar, A. (2013b) "Culture" 'Sous Rature': A Critical Review of the Notion of "Culture": Considerations from Cultural and Literary Studies. African Journal of History and Culture. 5 (9), pp. 58-71.

Assif, M., (2014).V.V. Gane shananthan's Love Marriage and Monica Ali’s Dinner with Dr.Azhad: Storying Memory, Trauma and Identity. International Journal of Comparative Literature \& Translation Studies, vol. 2, No. 1, pp 1-9.

Bhabha, H. (1994). The location of culture. London: Routledge.

Boehmer, E. (2005).Colonial \& Postcolonial Literature ( $2^{\text {nd }}$ Ed). Oxford: Oxford University Press.

Castells, M. (2004).The Power of Identity ( $2^{\text {nd }}$ Ed). West Sussex, UK: Wiley-Blackwell.

Clifford, J., (1997). 'Diasporas'. Cultural Anthropology, 9 (3), 302-38.

Deleuze, G. and Guattari, F. (2004) A Thousand Plateaus - Capitalism and Schizophrenia. Trans B. Massumi. London: Continuum.

Dunlop, R. (1999). Towards Negotiation of Difference.Canadian Journal of Education, vol. 24, pp. 57-69.

Fernandez, J., (2009). Diasporas: Critical and Inter-disciplinary Perspectives. Oxford: Oxford University Press.

Frie, R. (2011) Identity, Narrative, and Lived Experience after Postmodernity: Between Multiplicity and Continuity. Journal of Phenomenological Psychology, vol. 42, No. 1, pp. 46-60. 
Hunt, N. C. (2010). Memory, War and Trauma. New York: Cambridge.

Khan, A. (2010). The Independent reviews. Monday, 08 March 2010, available at:

http://www.independent.co.uk/arts-entertainment/books/reviews/mornings-in-jenin-by-susan-abulhawa-1917728.html

Kristeva, J. (1991). Strangers to Ourselves, New York: Colombia University Press.

Malouf, D., (2011). Mornings in Jenin. Publishers Weekly: Reed Business Information, available at:www.publishersweekly.com

Mishra, V. (1996). The diasporic imaginary: Theorizing the Indian diaspora. Textual Practice, vol. 10, No. 3, pp. 421447.

Mishra, V. (2005) No boxed gifts, Overland, vol. 181, pp. 73-82.

Moore, D. (1994). Decolonising criticism: Reading dialectics and dialogics in native American literatures. Studies in American Literatures, vol. 6, pp. 7-36.

Said, E. (1994). Culture and imperialism. London: Vintage.

Said, E. (2004).Humanism and Democratic Criticism.New York: Colombia University Press.

Sarup, M. (2005) Identity, Culture and the Postmodern World. Edinburgh: Edinburgh University Press.

Snaije, O., (2012). The many lives and languages of a Palestinian novel. Publishing Perspectives; The article is available at:http://publishingperspectives.com/2012/03/the-many-lives-and-languages-of-a-palestinian-novel/

Souza, L. (2007). 'Editor's preface', critical literacy. Theories and Practices, vol. 1, No. 1, pp.4-5.

Tölölyan, K. (2012). Diaspora studies - Past, present and promise.Working Papers , Paper 5. Oxford: International Migration Institute (IMI).

Yassin-Kassab, R. (2011) Mornings in Jenin. The Sunday Times Book Review, available at

https://login.thetimes.co.uk/?gotoUrl=http $\% 3 \mathrm{~A} \% 2 \mathrm{~F} \% 2 \mathrm{Fwww}$.thetimes.co.uk\%2Ftto $\% 2 \mathrm{Farts} \% 2 \mathrm{Fbooks} \% 2 \mathrm{~F}$ 